\title{
The Return of Industrial Policy and Revival of Pakistan's Economy: Possibilities of Learning, Industrial and Technology Policies
}

\section{Akbar Noman*}

\begin{abstract}
After being among the earliest countries to embark on the East Asian path, Pakistan fell away but was still among the ten fastest growing economies of the world during 1960-90. However, the seeds for the subsequent economic and technological malaise were also sown in that period. This paper provides an overview of recent theoretical and empirical work on industrial policies - more accurately labeled learning, industrial and technology (LIT) policies - and examines their implications for Pakistan. These include a selective, more sharply focused approach than the comprehensive agendas of reforms that have become common. Substantial islands of success with industrial policies have emerged in a variety of institutional and governance settings, different from those of the original East Asian developmental states. They offer valuable lessons. Raising the abysmally low level of investment in Pakistan is a requirement as well as an outcome and an instrument of industrial policies. This argues for a revival of development finance to stimulate investment as well as to direct it towards selective targets. How to mitigate the risks of this and other instruments of industrial policy to get the riskreward ratio right is another concern of the paper. An important target of such policies should be the technological upgrading of existing industries. There is enormous scope for doing so, with international comparisons suggesting that Pakistani manufacturing does poorly - both in terms of variance in productivity between firms within an industry as well as in introducing new technologies and products. Whilst the constraints of the politics-governance-security/terrorism nexus are beyond the scope of the paper, their salience cannot be underestimated.
\end{abstract}

Keywords: Industrial policies, learning, technology, industrialization, development finance, Pakistan.

JEL classification: L52, L60.

\footnotetext{
* Senior Fellow, Initiative for Policy Dialogue, Columbia University, New York.
} 


\section{Introduction}

After a long exile during which industrial policy (IP) had become unmentionable among mainstream economists, it has again become respectable. The literature extolling the case for IP has mushroomed in recent years, with a spate of publications both on its theory and practice. Justin Lin and Joe Stiglitz give the title "The Industrial Policy Revolution" to the two volumes emerging from two conferences/roundtables organized by the International Economic Association (see Stiglitz \& Lin, 2013; Stiglitz, Lin, \& Patel, 2013). ${ }^{1}$ In the foreword to the volumes, the then president of the association, Joseph Stiglitz, observes that "the roundtables were convened in recognition of the fact that industrial policy is a sort of lynchpin in the economics of development, that the countries that have been most successful in development have undertaken a wide variety of industrial policies and different countries can and should learn from these experiences."

The IP that Stiglitz and others speak of is not confined to industry, but also pertains to other activities, particularly in which learning and technological change are important, ranging from the information technology (IT) sector to agriculture with the "Green Revolution" in India and Pakistan being, arguably, a prime example of success with IP. ${ }^{2}$ Hence, as Noman and Stiglitz $(2011,2015)$ propose, they are more accurately referred to as "learning, industrial and technology" (LIT) policies, which would also serve to get away from the misconceptions and knee-jerk reactions that the term "industrial policy" evokes (the terms are used interchangeably here, given the familiarity with "industrial policy").

Notwithstanding this revival of LIT policies, strong objections and resistance remain from recalcitrant adherents of the neoliberal orthodoxy that was manifested in the so-called Washington Consensus. A more qualified and nuanced set of concerns have also been raised, revolving around issues of governance and rent seeking, and ones that most proponents of IP in the new literature recognize. Thus, they also focus on mitigating the risks and getting the risks-rewards ratio right. It should be noted that risks, failures, and governance challenges are no preserve of LIT policies: they arise in almost all spheres, including programs of

${ }^{1}$ Also see, for example, Chang (2002, 2013); Lin (2012, 2014); Cimoli, Dosi, and Stiglitz (2009); Noman and Stiglitz (2011, 2015); Greenwald and Stiglitz (2006); Stiglitz and Greenwald (2014); Mazzucato (2013); Andreoni (2015); Primi (2015), and several other works listed in the references.

${ }^{2}$ For an elaboration, see, for example, Noman and Stiglitz (2011). Hosono (2015a) includes the technological change that transformed vast tracts of what were once barren agricultural lands in Brazil as one of the five cases of outstanding success with IP that he examines. 
liberalization and privatization that also can be - and have been - captured and give rise to enormous rents.

In Pakistan, too, there has been a revival of the case for IP, especially at the Lahore School of Economics, with a number of recent articles on the topic in the Lahore Journal of Economics (see, for example, Amjad, 2006; Haque, 2014; Burki, 2008; McCartney, 2014; Rahim, 2012). The particularities of Pakistan today that will have a vital bearing on whether and to what degree these and the economic policy proposals advanced in this paper will be effective or desirable will depend crucially on the politics that undergirds economic management.

Pakistan can be characterized as a "conflicted state", referring not only to the challenges of armed conflict and the battle against terrorism, but also to the priorities of policymakers. These refer to both conflicting priorities in economic policies and to the tension between economic and noneconomic objectives. One such type of conflict is that manifested in the form of rent seeking: some rents are more inimical to economic progress than others, and some can be good for economic growth. ${ }^{3}$ Some such conflicts are inevitable in all societies, but a modicum of consensus or coherence and consistency is essential for sustained success in the sphere of economics. What is involved in seeking and arriving at such a consensus is beyond the scope of this paper. However, it is premised on a sufficient resolution of these different types of conflicts to allow adequate implementation of at least the less challenging - in politico-institutional terms - of its recommendations.

The theoretical case for LIT policies has been bolstered and nuanced in recent years by two factors: (i) the focus on externalities in learning and in discovery, which Stiglitz and Greenwald (2014) and Hausmann and Rodrik (2002), respectively, have emphasized; and (ii) the importance of economic structure, which has long been recognized (see Ocampo \& Ros, 2011), but revived recently notably in Lin's "New Structural Economics" (2012) and in Ocampo's writings (see, for example, Ocampo, Rada, \& Taylor, 2009). These considerations strengthen the case that Noman and Stiglitz $(2011,2015)$ make for using LIT rather than IP to more accurately capture what such policies should be about.

\footnotetext{
${ }^{3}$ Rents are pervasive in all economies and related corruption not uncommon. However, some rents may be good for economic growth and transformation, with dynamic gains outweighing static losses, such as those associated with industrial polices in success cases - including, notably, in the East Asian stars. Patents are another notable example of the recognition that some forms of rents can benefit economic and technological progress. The challenge is to direct rents toward productive and transformational activities rather than, say, to real estate overseas.
} 
One implication of the new or renewed emphasis on learning and structure is that it underlines the importance of manufacturing and the IT revolution. Indeed, Greenwald and Stiglitz (2006) make a case for general protection of the manufacturing sector in low-income developing countries on the grounds that it is likely to be more learning-intensive than other sectors that predominate at early stages of development. Since industries vary in their learning intensities, this also constitutes a basis and a criterion for LIT policies targeted at particular industries or activities.

As noted above, this recent literature strengthening the theoretical underpinnings of LIT policies is not unmindful of their pitfalls. The issues of design and implementation challenges are widely acknowledged, particularly in the often messy and weak institutional and governance contexts of developing countries such as Pakistan. There is no gainsaying that the choice of instruments and scope of LIT policies should depend on the competencies and priorities that underlie governance. Often, the mitigation of the risks of state capture and rent seeking calls for broadbased "horizontal" policies (such as undervalued exchange rates or technical training) or very narrowly focused, carefully circumscribed "vertical" policies pertaining to obvious low-hanging fruits, i.e., measures with low risks relative to rewards. It should also be noted that there are many examples of failed attempts at IP but it is difficult to parse the causes of the failures. They were often the result of inappropriate macroeconomic management or poor governance. Moreover, as noted above, risks and governance challenges arise in all spheres of economic management, not just LIT policies.

In addition to these conceptual and theoretical elaborations, a number of empirical studies have emerged in recent years. One strand, notably the work of Chang $(2002,2013)$, emphasizes the vital role LIT policies played in the historical experience of the now developed countries. He shows that this was the case, not just for those that caught up with the most advanced economies in the 19th and 20th centuries, but also the original advanced economy, the UK, where the industrial revolution was born. Earlier, Gerschenkron (1962) had shown the importance of the state with IP-style interventions in European industrialization.

The second strand of recent empirical work goes beyond the focus on the original four East Asian "tigers" (Korea, Taiwan, Singapore, and Hong Kong) - as analyzed notably in the classic works of Amsden (1989) and Wade (1990) - to examine cases of success elsewhere (e.g., Brazil, Ethiopia, Bangladesh, Chile, China, Thailand, and Mauritius). Earlier, the World Bank's (1993) study of the "East Asian miracle" was a notable 
exercise in extending the analysis beyond the four tigers plus Japan to include Indonesia, Malaysia, and Thailand among the "miracle" economies of the region. But, in its final version, the study goes to great lengths to underplay the role of IP. At times, it seems to verge on making the seemingly astonishing claim, first, that the East Asian "miracle" happened not because of, but despite, IP - astonishing, especially in the light of very detailed and careful research that shows otherwise, including notably Amsden $(1989,2001)$ and Wade (1990). Second, that, if and to the extent IP did not have a negative impact in the eight countries the report examines, other countries should not try to emulate them because they lack the allegedly unique institutional and political economy setting of the East Asian "miracle" countries, which allowed rapid development to coexist with IP.

The more recent set of empirical studies - as well as, arguably, the aforementioned World Bank study, notwithstanding its protestations bring out the heterogeneity of conditions and circumstances in which IP can work, as also recognized by the report of the Growth/Spence Commission (Commission on Growth and Development, 2008). The degrees and nature of success with LIT policies (as well as details of policy design) also vary with several cases of sectoral or subsectoral success with substantial overall economic impact, as distinct from the full-fledged, wideranging, and more systematic LIT policies of the classic East Asian kind (see, for example, Oqubay, 2015; Hosono, 2015; Abebe \& Schaefer, 2015; Andreoni, in press; Shimada, in press; Chandra, 2013; Narrainen, 2013).

There are potentially important lessons for Pakistan in these partial but significant successes in taking the next steps to revive LIT policies. This is illustrated by McCartney's (2014) focus on the lessons for Pakistan's textile industry from Bangladesh's garment export performance. More broadly, there are lessons to be learned from such (substantial) islands of success in countries with varying degrees of complex political circumstances at some distance from the (somewhat idealized) full-fledged "development states" of East Asia: Japan, Korea, Taiwan, and Singapore. ${ }^{4}$

In this context, there is a great deal to be said for moving away from the wide-ranging, almost all-encompassing reform programs that have been proposed both in some Government of Pakistan publications and in many reports of international and outside agencies, as McCartney (2014) emphasizes. Such long lists of reforms became common in many

\footnotetext{
${ }^{4}$ Bangladesh, with its highly polarized, personality-driven, dysfunctional politics is a particularly striking example of how an island of success can emerge in problematic governance settings.
} 
countries especially during the era of "conditionality" based on the Washington Consensus. ${ }^{5}$ Aside from the flaws in any specific proposals, they attempt to pursue the best, the enemy of the good, and lead to paralysis in the face of the overwhelming nature of the tasks. ${ }^{6}$ This could be said to be a lesson of reform programs: they have to be mindful of the capacity to implement reforms and, hence, of priorities and sequencing (see, for example, Noman \& Stiglitz, 2013, 2015a).

The rest of this paper is organized as follows. Section 2 provides an overview of Pakistan's development experience and the context for LIT policies. Section 3 turns to which IPs would be appropriate for Pakistan's economy in the light of its past and current conjecture. In doing so, it focuses on the lessons for Pakistan from recent empirical work on what has worked in contexts other than the classic East Asian cases, where islands of success have emerged. These are deemed more relevant for Pakistan today. Section 4 focuses on policies aimed at technological upgrading in general rather than any particular area. Section 5 is devoted to concluding comments.

\section{Pakistan: Past and Present}

It is ironic that Pakistan, which was among the first of the "East Asians" emulated by Korea in the early 1960s, has now to relearn not only from the East Asians who have left it far behind, but also lesser, albeit significant, successes elsewhere.

Pakistan was at the forefront of export promotion, while retaining very high levels of protection and what has been labeled an "import substitution industrialization" strategy. In 1965, its manufactured exports at US\$ 190 million (current \$) were almost double those of Korea (US\$ 104 million); some 42 percent and 15 percent higher than Brazil and Mexico, respectively; and exceeded the combined total of such exports from Indonesia, the Philippines, Thailand, Turkey, and Malaysia. By 1985, exports of manufactures from Pakistan, at US\$ 1,731 million, were well below all these countries' exports (manufactures), ranging from 80 percent of the level in Indonesia to 6 percent of that in Korea.

\footnotetext{
${ }^{5}$ For the more general case against attempting too many reforms too quickly, especially the African experience therewith, see Noman and Stiglitz (2015).

${ }^{6}$ The most recent examples of such overwhelming laundry lists of reforms for Pakistan include the World Bank (2013) and a series of papers it has published with the caveat that they reflect the views of the authors and not necessarily of the Bank. These are Speakman, Afzal, Yuge, and Hanna (2012); López-Calix and Touqeer (2013); and Bennmessaoud, Basim, Cholst, and López-Calix (2013). All these are available on the World Bank website.
} 
Notwithstanding the exogenous shocks of the war with India in 1965 (and the associated impact on aid inflows), the 1971 war and the break-up of the country as well as the "policy shocks" that followed in its aftermath, ${ }^{7}$ the growth momentum was such that, over the three decades ending in 1990, Pakistan's annual GDP growth rate placed it among the top ten countries, ${ }^{8}$ albeit in aggregate rather than per capita terms (Table 1). This, though, was also an era where the "Green Revolution" in agriculture, some fortuitous exogenous "shocks", and unsustainable fiscal expansion in the 1980s boosted Pakistan's growth.

Table 1: The ten fastest growing economies, 1960-90

\begin{tabular}{llcc}
\hline & Country & $\begin{array}{c}\text { Annual GDP growth rate } \\
\text { 1960-90 (percent) }\end{array}$ & $\begin{array}{c}\text { Annual CPI inflation } \\
\mathbf{1 9 6 0 - 9 1} \text { (percent) }\end{array}$ \\
\hline 1 & Republic of Korea & 9.3 & 12.2 \\
2 & Hong Kong & 8.7 & 7.6 \\
3 & Taiwan (China) & 8.3 & 6.2 \\
4 & Singapore & 8.0 & 3.6 \\
5 & Thailand & 7.5 & 5.6 \\
6 & China & 6.6 & 3.4 \\
7 & Japan & 6.6 & 4.9 \\
8 & Malaysia & 6.5 & 3.4 \\
9 & Egypt & 6.2 & 8.3 \\
10 & Pakistan & 6.1 & 7.8 \\
\hline
\end{tabular}

Notes: The table excludes countries with populations of under 2 million in 1990.

Among economies with an annual GDP growth rate of at least 5 percent over the 30 years (and populations greater than 20 million in 1990) were the following: Turkey (5.6 percent), Kenya (5.5 percent), Brazil (5.3 percent), and Mexico (5.0 percent). India's GDP grew at 4.4 percent during this period.

Three countries with populations of 1-2 million showed annual GDP growth rates exceeding 6 percent during 1960-90: Oman (12.3 percent), Botswana (10.4 percent), and Lesotho (6.4 percent). The oil sheikhdom Oman should qualify for some sort of world record for an annual GDP growth rate of 39.7 percent during 1965-70.

Source: World Development Indicators (http:/ / data.worldbank.org/data-catalog/worlddevelopment-indicators).

Since 1990, Pakistan has fallen far out of the top rankings of the GDP growth league, with a rate of around 4.4 percent a year over 19902010. Figure 1 shows the ten fastest growing economies (excluding oil exporters) and their annual growth rates during these two decades. India

7 Much of the country's manufacturing and finance was nationalized, bringing to an end the Korean-style "chaebols" that were, arguably, emerging then.

${ }^{8}$ Excluding countries with populations of less than 2 million in 1990. 
took over as the growth leader in South Asia and all other economies in the region had a GDP growth rate higher than that of Pakistan, with Sri Lanka averaging 5.6 percent and Bangladesh 5.4 percent. Given that Pakistan has the highest population growth rate in South Asia, its growth in per capita terms lagged even further behind the other economies in the region.

Among the top ten countries of 1990-2010, in terms of GDP growth, Ethiopia is a particularly interesting and illuminating case. ${ }^{9}$ Under the late Prime Minister, Meles Zenawi, it deliberately articulated and pursued policies emulating East Asia in the mid-to-late 1990s, in particular LIT policies. After a lackluster performance in the first half of the 1990s (when civil war still raged and the country split up with Eritrea, becoming independent), growth began to pick up in the late 1990s to the extent that, during 2000-10, Ethiopia's annual growth rate at 8.8 percent was second only to China's (10.7 percent) in the world. It has continued to grow at roughly similar rates after 2010. Its industrial or LIT policies are elaborated below and raise the question, if Ethiopia with much less of an entrepreneurial-managerial base can do it, why can't Pakistan and how might its lessons be learned.

Figure 1: Annual GDP growth rates, 1990-2010 (\%)

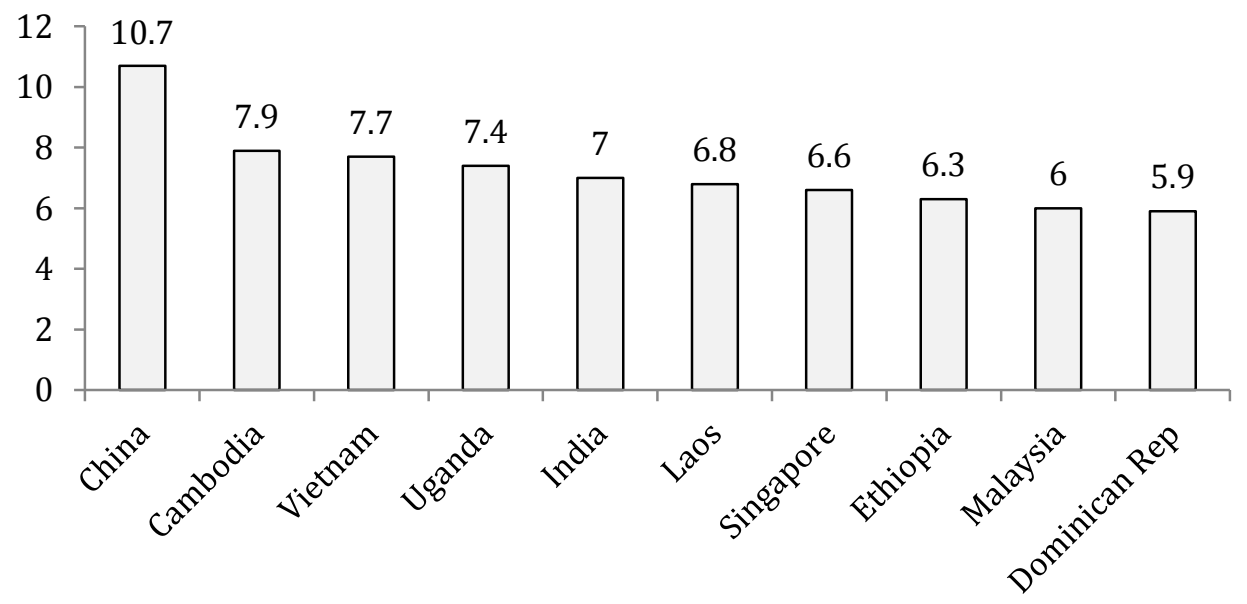

Note: The figure gives the averages of the annual growth rates in the two decades 1990-2000 and 2000-10. The three countries heavily reliant on oil exports, which were in this growth league, are Mozambique (7.0 percent), Kuwait (6.7 percent), and Sudan (6.1 percent).

Source: World Development Indicators (http://data.worldbank.org/data-catalog/worlddevelopment-indicators).

${ }^{9}$ Ethiopia's story is discussed at some length in Noman and Stiglitz $(2011,2015)$. 
Before turning to what might be done in Pakistan, it would be in order to glance quickly back at what changed between 1960-90 and 19902010 that transformed the country from among worldwide leaders in the growth league with the fastest growing economy in South Asia to a laggard with the slowest growing economy in the region.

Arguably, the seeds for the slowdown were sown in the 1970s with the disruptions resulting from war and the break-up of the country, combined with ill-conceived populist policies and nationalization. While much of that was reversed in the 1980s, the decade was one of facile growth ${ }^{10}$ and one in which a different set of seeds was sown for the subsequent slowdown (it should also be noted that the growth impetus provided by the Green Revolution in the late 1960s and 1970s had also begun to dissipate by the 1980s).

This 1980s set of bad seeds refers to the following phenomena. The first was heavy domestic borrowing at very high interest rates that allowed unsustainably expansionary fiscal policies in the 1980s and that were at the heart of the macroeconomic crises and consequent austerity programs with a series of IMF bailouts - that have shackled growth since the early 1990s. Much of this fiscal stimulus was not reflected in public expenditures of the sort that were good investments for sustained future growth.

Second, arguably, was the germination of the politics-governancesecurity nexus with the deterioration in the security situation and the rise of terrorism. Associated with this was the worsening of foreign attitudes and business sentiments and costs of doing business. Third, another obvious candidate among the causes for the deceleration, was the neglect of infrastructure and human development/capital during the fiscal consolidation required after the binge of the 1980s and attendant growing bottlenecks, especially of electricity.

Public sector development expenditures bore much of the brunt of attempts to cut fiscal deficits. However, even in the heyday of its growth performance, Pakistan grossly underinvested in human development. This underinvestment was in sharp contrast to the East Asian economies that sustained rapid economic growth and transformation and no doubt contributed to the reasons Pakistan was unable to do so. (Another such important contrast was that, unlike East Asia, growth was not widely shared

${ }^{10}$ Aside from unsustainable fiscal expansion, growth was facilitated by the expansion in domestic demand made possible by Afghan war-related foreign-financed expenditure and (more speculatively) increased drug smuggling. See Noman (1992). 
in Pakistan, which resulted in political turmoil, especially the tensions that culminated in the erstwhile East Pakistan becoming Bangladesh.)

A fourth reason, though not unrelated to the previous ones, was the depressed level of aggregate investment. Even in its high-growth phase, Pakistan was not much of an investor with the investment-to-GDP ratio hovering around 20 percent during 1960-90. In recent years, it has declined to some 15 percent. Clearly, with that sort of investment level, no country can grow at anything approaching 6 percent a year. It is also most unlikely to succeed in technological upgrading or more generally in pursuing LIT policies.

That Pakistan acutely needs to do so is well documented. Several studies document the technological quagmire surrounding the country's manufacturing and exports (see Amjad, 2006; Haque, 2014; Lall \& Weiss, 2004; Hausmann, Hwang, \& Rodrik, 2005; Kemal, 2006; World Bank, 2013; Asian Development Bank, 2003). Thus, Pakistan does very poorly on the assorted standard indicators of technological development: sophistication of exports, ISO certification, patents, availability of key high-level skills, research and development, and so on.

\section{LIT Policies}

This section describes the LIT policies on which Pakistan should focus.

\subsection{Investment and Development Finance}

The aforementioned calls for a revival of IP in Pakistan make a compelling case, the more so in light of the literature referred to above. The focus here is on elaborating some important policy implications of doing so.

First and foremost is the importance of raising investment from its abysmal level of roughly 15 percent of GDP. The second challenge is to direct investment toward promoting industrialization and other activities that lead to learning and technological upgrading. The first proposal (discussed below) pertaining to finance serves both as an outcome and an instrument of LIT policies. It is also the most challenging one and likely to be the most controversial. The subsequent policy proposals are roughly in descending order of challenge and controversy, ending with some bordering on being "no-brainers", i.e., providing opportunities of low risks and high returns. 
Before turning to economic policy, there is no gainsaying that an important impediment to raising investment in Pakistan is the country's security situation - as highlighted by both the private sector representatives who spoke at the conference at the Lahore School of Economics (at which a preliminary version of this paper was presented).

In the realm of economic policy, one implication of reviving IP in the country that is analytically compelling, though demanding in institutional and governance terms, is the high risk-high reward action of establishing or reviving development finance institutions (DFIs). There is no gainsaying that access to finance on attractive terms can both stimulate overall investment and be used to direct it. ${ }^{11}$ Earlier in Pakistan's past, two DFIs, the Pakistan Industrial Credit and Investment Corporation (PICIC) and the Industrial Development Bank of Pakistan (IDBP), played a vital role in creating a class of industrial capitalists-entrepreneurs and in the rapid industrialization of the 1950s and 1960s (see Papanek, 1967; Lewis, 1970). They demonstrated the powerful impact that DFIs can have in raising investment levels. ${ }^{12}$ Long-term loans at moderate-to-low interest rates can serve as one way to socialize the risks of investment - a mechanism that played an important role in promoting not only investments, but also savings in the "miracle" economies of East Asia, because the powerful incentive to invest also served to enhance corporate savings (World Bank, 1993; Stiglitz \& Uy, 1996).

The case for mobilizing development financing to stimulate investment is made the more compelling by the severe constraints on public investment or development expenditures on account of the fiscal position. The great difficulties Pakistan has had in raising its extremely low tax-to-GDP ratio in the face of the compulsions for fiscal consolidation are unlikely to be eased speedily. There is then a prima facie case for development finance to be also directed at public-private partnerships in the provision of public or quasi-public goods, especially in the spheres of infrastructure and perhaps human development (though the scope for public-private partnerships in the latter is likely to be confined to highlevel technical education).

However, this raises a number of issues revolving around governance and the capacity to run DFIs effectively - in particular to guard

${ }^{11}$ Burki (2008) notes the importance of appropriate finance for IP, but suggests focusing on small and medium enterprises and on utilizing new financial instruments developed in recent years, such as private equity and venture capital.

${ }^{12}$ On the general case for development banks, see Griffith-Jones and Cozzi (in press). 
against their capture by politically powerful rent-seekers. Such capture marred the experience with nationalized commercial banks, particularly in the 1980s and 1990s. Careful attention needs to be paid to how the risks might be mitigated (later on, this paper provides some initial thoughts on how to go about doing so). There is no gainsaying, however, that in the political context - or what Mushtaq Khan calls "political settlement"13 - of Pakistan today, DFIs would be a bold and risky venture. Perhaps that is why Burki (2008) refrains from proposing them whilst emphasizing the importance of reviving development finance. At any rate, his proposals for mobilizing new instruments such as venture capital and equity finance deserve attention, but are unlikely to make anything like the impact that more conventional development finance can, in raising investment.

Success in this venture is likely to be particularly contingent on easing the political constraints that were emphasized at the outset, with political commitment to adequate space for such technocratic measures. In this regard, it is worth noting that one of the architects of India's economic reforms of the past two to three decades, Montek Singh Ahluwalia, has emphasized the importance of political consensus, arguing that a strong consensus on even weak or gradual reforms has served India well. ${ }^{14}$

In designing the details of the operational procedures and policies of the DFIs (including perhaps on insulation from "political" lending), Pakistan could seek technical assistance or advice from successful development banks. Whilst the experience of such banks in advanced countries - such as Germany's KfW or European Investment Bank - or in the full-fledged developmental states of East Asia could provide useful lessons, the experiences of reasonably successful development banks operating in rather less advanced developed or developmental states are likely to be particularly relevant. Aside from lessons from Pakistan's own past in the heyday of PICIC and IDBP, the most obvious candidate for such learning is probably the Brazilian Development Bank, the BNDES. The Corporación Andina de Fomento in the Andean region and the Development Bank of Ethiopia are other examples of possible candidates for emulation.

Another way to mitigate risks and strengthen the ability of current and future governments to resist political pressure would be to make the

\footnotetext{
${ }^{13}$ Khan (2000) analyzes the political constraints that hampered the efficacy of IP in Pakistan. In his later writings, he labels such political economy considerations "political settlements" and elaborates on the concept.

${ }^{14}$ More precisely, he attributes India's success to a strong consensus on weak or gradual reforms (see Ahluwalia, 2002).
} 
operations of the DFI, especially lending decisions and repayments, transparent by publicizing them and subjecting them to outside scrutiny, including possibly by Parliament and its Public Accounts Committee. Another such measure could take the form of having outsiders serving in some capacity to oversee lending decisions. These could be, for example, representatives of multilateral development banks - who would then also be more inclined to provide financing - or civil society representatives with impeccable credentials. The latter could be either from domestic or international NGOs or some combination thereof.

In any event, the sphere of operation of any DFI in Pakistan should be carefully and narrowly circumscribed to the sort of activities we identify later on as providing a particularly high reward-to-risk ratio or what might be termed the "little-or-no-brainers" for LIT policies in the country. Another option would be not an altogether new institution, at least to begin with, but a development finance window in an existing institution.

Another crucial issue is that of the DFI's source of funding or its deposits/liabilities. In their prime, PICIC and IDBP relied heavily on World Bank financing. It is highly unlikely that the Bank would reverse its policy of cutting off such support to DFIs in the foreseeable future. Given the state of public finances, the banking sector, and nonbank financial institutions in Pakistan, DFI lending on an adequate scale is likely to require external financing. Among the more promising sources of concessional financial support, China is probably the most prominent. The New Development Bank is also a possibility. Another option could be providing a stake to some sovereign wealth fund such as the Malaysian "Khazanah", which actually provides support to LIT policies in Malaysia.

\subsection{Targeting Activities in a Selective "Islands" Approach}

We turn now to the less challenging and less controversial questions of (i) what particular industries and technological upgrading to promote, and (ii) how to go about doing so with (ideally) or without (possibly) an effective DFI.

On choice of industry, recent proposals include Amjad's (2006) call for targeting IT, Rahim's (2012) suggestion to subcontract in international value chains, Haque's (2014) idea of focusing on export competitiveness, and Burki's (2008) proposal to pick "winners" focused on small and medium enterprises, notably agro-processing, small-scale engineering, leather products, and IT in the Punjab. Burki also calls for analytical work 
to pick "winners" by carefully assessing the opportunities in both domestic and foreign markets.

In identifying the targets of LIT policies, one promising approach is that proposed by Lin (2014), who argues that, "for an industrial policy to be successful, it should target sectors that conform to the economy's latent comparative advantage. The latent comparative advantage refers to an industry in which the economy has low factor costs of production but the transaction costs are too high to be competitive in domestic and international markets." In answering the question, "How are governments able to pick the sectors that are in line with the economy's latent comparative advantages?", Lin says that a "short answer is to target industries in dynamically growing countries with a similar endowment structure and somewhat higher income." Elsewhere, he has spoken of "somewhat higher income" as being not much higher than roughly two or three times the per capita income of the economy at hand.

The Lin proposal need not be the only route to identify targets for LIT policy support, but it would be a useful starting point in Pakistan today. Chang (2002), in particular, emphasizes that, while Lin's "latent comparative advantage" approach has considerable merit in mitigating the risk of picking "losers", it is a little too cautious and does not accord with the experience of some countries, especially in East Asia, that also sought and created dynamic comparative advantage in industries outside the ambit of Lin's "latent comparative advantage". Perhaps one such opportunity is provided by the development of niches in the global value chain of "green" technology: given the critical importance of dealing with climate change, this is going to be an area of rapidly growing global demand.

At any rate, in Pakistan there is one highly promising area to target that is consistent with the "latent comparative advantage" approach: the long-established textiles sector. It has remained mired in low-productivity activities producing output at or near the lowest end of technological sophistication and demand dynamism. Among the many calls for upgrading Pakistan's textiles sector is that of McCartney (2014) who seeks to extract lessons for Pakistan from the experience of Bangladesh.

\subsection{Creating Islands of Success}

McCartney's (2014) proposal accords well with the suggestion made above for Pakistan to learn lessons from "islands" of success in a variety of countries with varying proximities to a developmental state. This 
section elaborates on some of the examples cited in the opening section. One highly illuminating exercise by Hosono (2015a) examines what he labels as five "outstanding cases of success" in different countries and sectors. These are (i) automobiles in Thailand, (ii) the "Cerrado" in Brazil (which was transformed from a vast expanse of barren land to a place of highly productive agriculture), (iii) the garments industry in Bangladesh (most relevant for Pakistan), (iv) salmon fisheries in Chile, and (v) Singapore's upgrading of its industrial sector from a labor-intensive to a knowledge-intensive base (least relevant for Pakistan). ${ }^{15}$ Noman and Stiglitz (2015b) summarize Hosono's (2015a) work as follows:

Hosono seeks to extract insights from these rich case studies on how the various considerations that go into the making of industrial policy interact in practice in successful cases. He focuses in particular on the acquisition of capabilities; the creation of a learning society; using and altering factor endowments to move from static to dynamic comparative advantage; compensation for the positive externalities generated by the costs of discovery by pioneer firms; and the management of the pressures generated by globalization and the ideology and interests of "free-marketers".

Hosono's five case studies illustrate how the general principles of good industrial policy vary in their translations into different contexts. But they also illustrate the mutual causality between industrial development and economic transformation, on the one hand and the "constant development of capabilities and knowledge through learning". In the case of Singapore, in particular, Hosono emphasizes the crucial role of "learning to learn". These cases also serve to bring out that reasonably good institutional "islands" created for specific purposes, as distinct from an overhaul of the entire institutional structure, can be highly effective [emphasis added] ... Hosono's paper also brings out the important role that the development of physical infrastructure plays as an instrument of industrial policy.

Another example of the island approach, and one of particular interest that is examined in some detail below, is that of Ethiopia. As noted above, excluding countries with oil exports and discoveries, Ethiopia's

${ }^{15}$ Other examples of such case studies are Chandra (2013) and Narrainen (2013). 
economy grew at a rate second only to China during 2000-10, and it was second to none between 2004 and 2011, when the country's GDP grew at 10.6 percent per year. The LIT policies that the country pursued were based on a strong commitment from the political leadership, especially Prime Minister Meles Zenawi, a veritable scholar who had carefully studied and drawn the lessons of East Asian success; he passed away in 2012 but the late Prime Minister's policies are being continued under his successor.

There is, of course, a lag in the recognition of economic success and Ethiopia's is just beginning to be appreciated, especially with two recent publications, including Oqubay (2015) and Abebe and Schaefer (2015). As Justin Lin comments in his endorsement of Oqubay's volume, "Ethiopia is a development miracle in [the] making ..." Be that as it may, the LIT policies it has pursued thus far provide illuminating lessons.

Ethiopia's IP is probably best known for its success in floriculture and leather goods, which is what it began with, but other areas such as textiles and garments as well as wine are also beginning to bloom. Before turning to the better-known first two cases or "islands" on which Ethiopia concentrated initially, it should be noted that the country is also going beyond them to two other areas. Thus, the recently established largest of the Turkish-owned garments and textiles factories employs some 12,000 workers and is expanding; a UK glove manufacturer has established three factories in two years; and in 2014, a winery and vineyard resulting from foreign investment was inaugurated (Oqubay, 2015).

Abebe and Schaefer (2015) have a narrower focus than Oqubay (2015) - concentrating on floriculture and leather processing. These are sectors that have developed rapidly, with a significant overall impact on the economy. Exports of floriculture rose from a minute level of well under US\$ 1 million in 1997 to US\$ 210 million in 2011. The promotion of leather goods was a slower process and its exports, after rising gradually between 2005 and 2010, are now soaring dramatically, with a major Chinese shoe producer, Huajian, having established a large factory in Ethiopia. ${ }^{16}$ By 2014, the factory had already begun to produce some 2,000 pairs of shoes per day for designer labels and employed some 1,600 workers. Huajian is implementing highly ambitious plans to expand its production with the aim of generating US\$ 4 billion in annual exports within a decade.

\footnotetext{
${ }^{16}$ This resulted from a meeting that Zenawi sought with Huajian during his visit to China in 2011.
} 
The expansion of these two sectors alone contributed to a significant transformation of the Ethiopian economy, whose total exports in 2012 amounted to about US\$ 3 billion. This is akin to the role of garments in Bangladesh, but the "transformation" is not confined to one sector, as Ethiopia is pursuing more broad-based and deliberate IPs.

One of the key issues of LIT policies concerns how learning comes about. Similar to the case of Bangladesh garments exports that Hosono (2015a) examines - in which Korean firms initially trained many Bangladeshi workers in Korea - Huajian is sending a significant proportion of its local employees for training to its headquarters in China.

According to Abebe and Schaefer (2015), it was easy to pick the floriculture and leather sectors for support as they have "production organizations and technological intensities that suit the labor-abundantcapital-scarce nature of the Ethiopian economy." Both sectors benefitted from a wide range of IP interventions. Abebe and Schaefer's study extricates both the similarities in policy actions as well as how policies were tailored to the specific requirements of each sector. The common elements in the LIT policy support to both sectors that were especially important were (i) access to finance on fairly attractive terms through the Development Bank of Ethiopia, ${ }^{17}$ (ii) close government-business consultations, and (iii) flexibility in altering forms and degrees of support.

Regarding the differences in policies towards the two sectors and designing them to deal with sector specific challenges,

... the following are noteworthy: The leather sector was characterized by the need to overcome coordination failures that required several problems along the value change to be tackled simultaneously to achieve global competitiveness. The dominant challenges in the floriculture sector on the other hand pertained to logistics, land acquisition and initial capital (that needed to be financed at terms that were not too short-term and costly for such investments) (Noman \& Stiglitz, 2015b).

In leather manufacturing, the government very actively supported the acquisition of technological capabilities: setting up a leather training institute whose training programs often involved foreign experts, and

${ }^{17}$ Ethiopia is rare in Africa in still having a development bank after the wave of financial liberalization that closed down such banks not only in Africa, but also in many other developing countries. 
subsidizing the employment of such experts by domestic firms. The state also provided land and semi-constructed factories as well as basic infrastructural facilities in industrial zones. Tax and regulatory policies used to encourage upgrading included a ban on exports of raw hides and skins, and export taxes on minimally processed low value-added products.

For cut flowers, industrial policies were tailored to provide land at relatively modest prices in proximity of the airport, as well as reliable airfreight services, including the promotion of air-conditioned transport to the airport and coordination with Ethiopian Airlines so that its flight schedule got the flowers to overseas markets, especially Amsterdam, at the appropriate time.

There are clearly many lessons Pakistan can learn from the carefully selective approach with a sharp and narrow focus on particular subsectors, probably no more than one or two to begin with. It should also be noted that Ethiopia's success was based on a substantial improvement in its abysmal physical infrastructure, especially in transport, communications, and energy. This reflected the mobilization and highly effective use of foreign assistance, driven by clearly articulated government priorities as part of the vision that guided its LIT policies.

\subsection{Targeting Technological Upgrading}

Aside from upgrading the textiles sector, a more general highly promising, low-risk target for LIT policies in Pakistan stems from the fact that the country exhibits one of the largest gaps between "best practice" and "average practice" in productivity and technology, with firms within the same industry often varyingly hugely on this count. This is among the findings of a wide-ranging paper on innovation policy for Pakistan by Speakman et al. (2012).

Speakman et al. demonstrate that there is substantial variation in productivity levels between firms in the same country in a sample of developing countries and that Pakistan is an extreme case: "Pakistan's variability is almost double the next comparator - the Philippines." (The other countries in the sample were Bangladesh, Brazil, Chile, Croatia, India, Indonesia, Mexico, and South Africa). They also find that a "few Pakistani firms" are highly productive and competitive, but the large majority are not - even in the same industry. Spreading the leading firms' technology to those that are far behind is an obvious and enormous

opportunity for LIT policies. The costs of discovery have already been 
borne with the premier firms having established that it works in Pakistan. Atkin et al. (2014) identify the misalignment of incentives mainly on account of the form of labor contracts that are among the constraints to upgrading to demonstrably profitable technologies.

In terms of policy prescriptions, Speakman et al. (2012) pay much attention to the institutions involved in innovation policy and make a large number of other recommendations based on 12 rather broad policy pillars. They note that the "policy mix required ... is a complex interaction of general business-enabling environment reforms, increased competitiveness, key infrastructure investments (mainly in ICT sector), appropriate firm-level support and establishing dynamic relationships between academia, firms and government." They express some support for subsidies for encouraging innovation, albeit in a muted fashion.

With regard to reforms of institutions, or what Speakman et al. (2012) label the "innovation ecosystem", they point to the multiplicity of ineffective institutions that are mainly in the business of paying salaries to their staff and the absence of a "nodal" agency and a coherent policy. Consolidation and reform of this moribund institutional framework is another obvious area for policy attention. Burki (2008) focuses in particular on reform of the Small and Medium Enterprise Development Authority.

In this context, it may well be worthwhile to seek or enhance the assistance of the Japan International Cooperation Agency under its program of support for "Kaizen", which it is expanding and implementing in several countries, including Ethiopia (see Shimada, 2015, for its success in Ethiopia). According to Hosono (2015b), "Kaizen is a Japanese concept which can be translated, literally, as 'improvement' or 'continuous improvement.' It is not easy to define kaizen in a strict sense since it corresponds to evolving initiatives and activities in the quality and productivity area and can very flexibly be adapted to each factory floor's context." Typically, Kaizen involves very little investment, but focuses on raising the productivity of the technology embodied in the pre-existing capital stock.

\section{Concluding Comments}

The recent revival of focus on the theory and practice of industrial/LIT policy with a mushrooming literature makes a compelling case for paying attention to how such policies can be adapted to the circumstances of a particular country. This paper attempts to do so for Pakistan. 
After a quick overview of the new literature, we sketched Pakistan's development story, which saw the country transformed from being among the leaders in growth and LIT policies to a laggard. A combination of the growth momentum of the earlier period of success, some fortuitous circumstances with opportunities for what we refer to as "facile" growth, and expansionary fiscal policies meant that Pakistan was among the world's ten fastest growing economies during 1960-90, albeit at the bottom and not in per capita terms. Its GDP per capita grew at a higher rate than that of any other economy in South Asia during those three decades. However, this was also a period in which the seeds of the subsequent stagnation were sown. Poorly conceived populist policies, including large-scale nationalizations, were mostly reversed in a relatively short period, but the fiscal profligacy of the 1980s necessitated austerity policies, subsequently with public investment in infrastructure bearing the brunt and little room for the big increase in expenditures on human development that Pakistan so badly needs.

Whilst the extent and quality of fiscal adjustment are debatable, that the fiscal legacy of the 1990s constrained economic growth and transformation for a prolonged period that has yet to end is not. Combined with the germination of a politics-governance-security nexus inimical to investment and economic progress, which became increasingly acute, these constraints were reflected in Pakistan becoming the slowest growing economy in South Asia during 1990-2010 with related technological stagnation. An abysmally low investment rate of some 15 percent of GDP both reflected and in turn contributed to the malaise.

We share the view of the broad thrust of several recent calls for the revival of some form of IP in Pakistan as an essential element of economic revival. A number of policy proposals are advanced in this paper, but we noted at the outset that they are predicated on the state becoming less conflicted. By that, we refer not only to the war on terrorism being successfully concluded, but also to a modicum of success in achieving some consensus or consistency regarding economic policy priorities and resolving the conflicts between economic and noneconomic objectives. These include those manifested in the form of rent seeking and whether and to what extent they are good or bad for economic progress. Such conflicts afflict all societies to varying degrees, but they are arguably especially salient for Pakistan at this juncture.

This set of issues is often subsumed under governance, which has been the subject of growing attention, and the emergence of an assortment 
of indicators and what has been labeled a "good governance" agenda. While there is no denying the importance of governance, this agenda confuses ends with means and makes the pursuit of the best the enemy of the good. What is feasible and needed is what Khan (2011) calls "growthenhancing" and Chang (2012) "good-enough governance."

Raising the very low level of investment is likely to depend significantly on that essentially political venture. It is vital if the economy is to break out of its technological stagnation, move to a sustainable higher growth path, and generate adequate employment. Higher investment levels are also, of course, essential both as an instrument and an objective of LIT policies.

One policy action for stimulating investment would be to revive development finance. DFIs played a crucial role in the earlier economic success of Pakistan, but they are at high risk of capture in the light of the subsequent experience with nationalized banks in the 1980s and 1990s. We propose various ways of mitigating those risks, including learning from the experience of successful DFIs in less pristine developmental states than those of East Asia, various ways of making DFI operations transparent and subject to outside scrutiny, and constricting lending to highly selective activities such as technological upgrading.

Naturally, the choice of instruments and scope of LIT policies should depend on the competencies and priorities that underlie governance. This paper identifies the targets and forms of appropriate LIT policies for Pakistan. In terms of targets, there are some obvious ones such as upgrading the textiles sector and narrowing the huge gap between best and average practice in Pakistani firms across the spectrum of industries. There are also several other targets proposed by others that have much merit, e.g., the IT sector and small and medium enterprises in light engineering or becoming subcontractors in international value chains. But the targets have to be chosen with great care, based on analytical work. One promising way of doing so discussed above is that of seeking to identify "latent comparative advantage" along the lines that Justin Lin suggests.

At least as important as identifying the low-hanging fruits - with high rewards in relation to risks - for targets of IP is the approach to designing such policies and their scope. Instead of comprehensive or wideranging LIT policies of the classic East Asian variety, this paper proposes a highly selective approach focusing on creating "islands" of success. We 
provide notable examples of success with such an "islands" approach, including that of Ethiopia, which has been at the top of the world's growth league in this century. If Ethiopia, starting with much less of an industrialbusiness class base and weak institutions (especially the bureaucracy), can do it, why can't Pakistan? The answer lies in Pakistan acquiring to some or sufficient degree, the sort of vision and commitment accorded at the highest levels of government in Ethiopia to economic priorities of the sort reflected in its LIT policies. Once upon a time, Pakistan arguably did so. 


\section{References}

Abebe, G., \& Schaefer, F. (2015). Review of industrial policies in Ethiopia: A perspective from the leather and cut flower industries. In A. Noman \& J. E. Stiglitz (Eds.), Industrial policy and economic transformation in Africa. New York, NY: Columbia University Press.

Ahluwalia, M. S. (2002). Economic reforms in India since 1991: Has gradualism worked? Journal of Economic Perspectives, 16(3), 67-88.

Amjad, R. (2006). Why Pakistan must break into the knowledge economy [Special edition]. Lahore Journal of Economics, 11, 75-87.

Amsden, A. H. (1989). Asia's next giant: South Korea and late industrialization. New York, NY: Oxford University Press.

Amsden, A. H. (2001). The rise of "the rest": Challenges to the West from lateindustrializing economies. Oxford: Oxford University Press

Andreoni, A. (2014). Structural learning: Embedding discoveries and the dynamics of production. Structural Change and Economic Dynamics, $29,58-74$.

Andreoni, A. (2015, February). Varieties of industrial policies. Paper presented at the IPD/JICA Task Force on Industrial Policy and Transformation Meeting, New York. Available at www.policydialogue.org

Asian Development Bank. (2003). Asian development outlook 2003: Competitiveness in developing Asia. Manila: Author.

Atkin, D., Chaudhry, A., Chaudry, S., Khandelwal, A., \& Verhoogen, E. (2014). Organizational barriers to technology adoption: Evidence from soccer-ball producers in Pakistan. Unpublished manuscript. Retrieved from http:/ /economics.mit.edu/files/9882

Bennmessaoud, R., Basim, U., Cholst, A., \& López-Calix, J. R. (2013). Pakistan: The transformative path (Report No. 80506). Islamabad: World Bank. 
Burki, S. J. (2008). Industrial policy: Domestic challenges, global imperatives, and Pakistan's choices [Special edition]. Lahore Journal of Economics, 13, 23-34.

Chandra, V. (2013). How Ethiopia can foster a light manufacturing sector. In J. E. Stiglitz, J. Y. Lin, \& E. Patel (Eds.), The industrial policy revolution II: Africa in the twenty-first century (pp. 541-568). New York, NY: Palgrave Macmillan.

Chang, H.-J. (2002). Kicking away the ladder: Development strategies in historical perspective. London: Anthem Press.

Chang, H.-J. (2013). Industrial policy: Can Africa do it? In J. Stiglitz, J. Y. Lin, \& E. Patel (Eds.), The industrial policy revolution II: Africa in the twenty-first century (pp. 114-132). New York, NY: Palgrave Macmillan.

Cimoli, M., Dosi, G., \& Stiglitz, J. E. (Eds.). (2009). Industrial policy and development: The political economy of capabilities accumulation. New York, NY: Oxford University Press.

Commission on Growth and Development. (2008). The growth report: Strategies for sustained growth and inclusive development. Washington, DC: World Bank.

Gerschenkron, A. (1962). Economic development in historical perspective: A book of essays. Cambridge, MA: Harvard University Press.

Greenwald, B., \& Stiglitz, J. E. (2006). Helping infant economies grow: Foundations of trade policies for developing countries. American Economic Review, 96(2), 141-146.

Griffith-Jones, S., \& Cozzi, G. (in press). The roles of development banks: How they can promote investment, in Europe and globally.

Haque, I. (2014). Toward a competitive Pakistan: The role of industrial policy [Special edition]. Lahore Journal of Economics, 19, 61-90.

Hausmann, R., \& Rodrik, D. (2002). Economic development as self-discovery (Working Paper No. 8952). Cambridge, MA: National Bureau of Economic Research. 
Hausmann, R., Hwang, J., \& Rodrik, D. (2005). What you export matters (Working Paper No. 11905). Cambridge, MA: National Bureau of Economic Research.

Hosono, A. (2015a). Industrial strategy and economic transformation: Lessons of five outstanding cases. In A. Noman \& J. E. Stiglitz (Eds.), Industrial policy and economic transformation in Africa. New York, NY: Columbia University Press.

Hosono, A. (2015b, February). Industry: Towards a learning society for inclusive and sustainable development. Paper presented at the IPD/JICA Task Force on Industrial Policy and Transformation Meeting, New York. Available at www.policy dialogue.org

Kemal, A. R. (2006). Key issues in industrial growth in Pakistan [Special edition]. Lahore Journal of Economics, 11, 49-74.

Khan, M. H. (2000). The political economy of industrial policy in Pakistan 19471971 (Working Paper No. 98). London: School of Oriental and African Studies. Retrieved from http:/ /eprints.soas.ac.uk/9867/1/Industrial_Policy_in_Pakistan.pdf

Khan, M. H. (2011). Governance and growth challenges for Africa. In A. Noman, K. Botchwey, H. Stein, \& J. E. Stiglitz (Eds.), Good growth and governance in Africa: Rethinking development strategies (pp. 5179). New York, NY: Oxford University Press.

Lall, S., \& Weiss, J. (2004). Industrial competitiveness: The challenge for Pakistan (Seminar Paper No. 2). Tokyo: Asian Development Bank Institute.

Lewis, S. R. (1970). Pakistan: Industrialization and trade policies. London: Oxford University Press.

Lin, J. Y. (2012). New structural economics: A framework for rethinking development and policy. Washington, DC: World Bank.

Lin, J. Y. (2014, June). Industrial policy revisited: A new structural economics perspective. Paper presented at the IPD/JICA Industry/Industrial Policy Task Force Meeting, Amman, Jordan. 
López-Calix, J., \& Touqeer, I. (2013). Revisiting the constraints to Pakistan's growth (Policy Paper Series on Pakistan No. PK 20/12). Washington, DC: World Bank.

Mazzucato, M. (2013). The entrepreneurial state: Debunking public vs. private sector myths. London: Anthem Press.

McCartney, M. (2014). The political economy of industrial policy: A comparative study of the textiles industry in Pakistan [Special edition]. Lahore Journal of Economics, 19, 105-134.

Narrainen, S. P. (2013). Industrialization: The Mauritian model. In J. Stiglitz, J. Y. Lin, \& E. Patel (Eds.), The industrial policy revolution II: Africa in the twenty-first century (pp. 569-584). New York, NY: Palgrave Macmillan.

Noman, A. (1991). Industrial development and efficiency in Pakistan: A revisionist overview. Pakistan Development Review, 30(4), 849-861.

Noman, A. (1992). Growth-oriented industrialization in Pakistan. Paper presented at the UNU-WIDER conference, Helsinki.

Noman, A., Botchwey, K., Stein, H., \& Stiglitz, J. E. (Eds.). (2011). Good growth and governance in Africa: Rethinking development strategies. New York, NY: Oxford University Press.

Noman, A., \& Stiglitz, J. E. (2011). Strategies for African development. In A. Noman, K. Botchwey, H. Stein, \& J. E. Stiglitz (Eds.), Good growth and governance in Africa: Rethinking development strategies (chap. 1). New York, NY: Oxford University Press.

Noman, A., \& Stiglitz, J. E. (2015a). Economics and policy: Some lessons from Africa's experience. In C. Monga \& J. Y. Lin (Eds.), The Oxford handbook of Africa and economics: Policies and practices (chap. 45). Oxford: Oxford University Press.

Noman, A., \& Stiglitz, J. E. (Eds.). (2015b). Industrial policy and economic transformation in Africa. New York, NY: Columbia University Press.

Ocampo, J. A., Rada, C., \& Taylor, L. (2009). Growth and policy in developing countries: A structuralist approach. New York, NY: Columbia University Press. 
Ocampo, J. A., \& Ros, J. (Eds.). (2011). The Oxford handbook of Latin American economics. New York, NY: Oxford University Press.

Oqubay, A. (2015). Made in Africa: Industrial policy in Ethiopia. Oxford: Oxford University Press.

Papanek, G. F. (1967). Pakistan's development: Social goals and private incentives. Cambridge, MA: Harvard University Press.

Primi, A. L. (2015). The return of industrial policy: (What) can Africa learn from Latin America? In A. Noman \& J. E. Stiglitz (Eds.), Industrial policy and economic transformation in Africa. New York, NY: Columbia University Press.

Rahim, S. (2012). Industrialization by fitting in: Acquiring technology through collaboration and subcontracting [Special edition]. Lahore Journal of Economics, 17, 83-102.

Speakman, J., Afzal, K., Yuge, Y., \& Hanna, J. (2012). Toward an innovation policy for Pakistan (Policy Paper Series on Pakistan No. PK 06/12). Washington, DC: World Bank.

Stiglitz, J. E., \& Greenwald, B. (2014). Creating a learning society: A new approach to growth, development and social progress. New York, NY: Columbia University Press.

Stiglitz, J. E., \& Lin, J. Y. (Eds.). (2013). The industrial policy revolution I: The role of government beyond ideology. New York, NY: Palgrave Macmillan.

Stiglitz, J. E., Lin, J. Y., \& Patel, E. (Eds.). (2013). The industrial policy revolution II: Africa in the twenty-first century. New York, NY: Palgrave Macmillan.

Stiglitz, J. E., \& Uy, M. (1996). Financial markets, public policy and the East Asian Miracle. World Bank Research Observer, 11(2), 249-276.

Wade, R. (1990). Governing the market: Economic theory and the role of government in East Asian industrialization. Princeton, NJ: Princeton University Press.

World Bank. (1993). The East Asian Miracle: Economic growth and public policy. Oxford: Oxford University Press. 
World Bank. (2013). Pakistan - Finding the path to job-enhancing growth: A country economic memorandum. Islamabad: Author.

Zenawi, M. (2011). States and markets: Neoliberal limitations and the case for a developmental state. In A. Noman, K. Botchwey, H. Stein, \& J. E. Stiglitz (Eds.), Good growth and governance in Africa: Rethinking development strategies (chap. 5). New York, NY: Oxford University Press. 